\title{
Extruded Corn Meal as a Partial Replacement for Steam Flaked Corn in Finishing Diets for Feedlot Cattle: Growth Performance and Digestive Function of Feedlot Cattle
}

\author{
L. Buenabad', A. Y. Jacinto' ${ }^{1}$, M. Montano', R. A. Zinn' ${ }^{2 *}$ \\ ${ }^{1}$ Department of Nutrition and Biotechnology of Ruminats, Instituto de Investigaciones en Ciencias Veterinarias, Universidad \\ Autónoma de Baja California, Mexicali, Mexico \\ ${ }^{2}$ Department of Animal Science, University of California, Davis, USA \\ Email: *razinn@ucdavis.edu
}

How to cite this paper: Buenabad, L., Jacinto, A.Y., Montano, M. and Zinn, R.A. (2019) Extruded Corn Meal as a Partial Replacement for Steam Flaked Corn in Finishing Diets for Feedlot Cattle: Growth Performance and Digestive Function of Feedlot Cattle. Open Journal of Animal Sciences, 9, 196-206. https://doi.org/10.4236/ojas.2019.92017

Received: January 23, 2019

Accepted: March 26, 2019

Published: March 29, 2019

Copyright $\odot 2019$ by author(s) and Scientific Research Publishing Inc. This work is licensed under the Creative Commons Attribution International License (CC BY 4.0).

http://creativecommons.org/licenses/by/4.0/

c) (i) Open Access

\begin{abstract}
Sixty-four Holstein steers $(247 \pm 4 \mathrm{~kg})$ were used in a 70 -d experiment to evaluate the effects of partial replacement of steam flake corn (SFC) with extruded corn meal (EC) on growth performance and dietary net energy. Treatments consisted of a steam flaked corn-based finishing diet containing $0 \%, 10 \%, 20 \%$, or $30 \% \mathrm{EC}$, where EC replaced $0 \%, 15 \%, 30 \%$, or $45 \%$ of SFC (DM basis). Replacement of SFC with increasing levels of EC did not affect ( $P>0.10)$ ADG, DMI, and gain efficiency. When EC replaced $15 \%$ to $30 \%$ of SFC, observed dietary NE was $99 \%$ of expected. Whereas, when EC replaced $45 \%$ of SFC, observed dietary NE was $94 \%$ of expected. Four Holstein steers $(210 \pm 7 \mathrm{~kg})$ with cannulas in the rumen and proximal duodenum were used in a $4 \times 4$ Latin square experiment to evaluate treatment effects on characteristics of digestion. Partial replacement of SFC with EC did not affect $(P>$ $0.10)$ flow of undegraded feed $\mathrm{N}$ and microbial $\mathrm{N}$ and to the small intestine, and ruminal microbial $\mathrm{N}$ efficiency (g microbial $\mathrm{N} / \mathrm{kg}$ OM fermented). Likewise, there were no treatment effects $(P>0.10)$ on ruminal digestion of $\mathrm{OM}$, $\mathrm{NDF}$, starch and feed N. As expected, total tract digestion of starch for all treatments exceeded 99\%. However, partial replacement of SFC with EC decreased total tract digestion of DM and OM (linear effect, $P=0.02$ ), and dietary DE (linear effect, $P=0.03$ ). These effects were more pronounced where EC replaced $45 \%$ of SFC. Partial replacement of SFC with EC did not affect $(P>0.10)$ ruminal $\mathrm{pH}$, total VFA concentration, molar proportions of acetate, propionate, and butyrate, and estimated methane production. It is concluded that partial replacement of SFC with EC does not have a beneficial ef-
\end{abstract}


fect on ruminal microbial efficiency and digestive function. The feeding value of extruded corn for feedlot cattle is comparable to that of steam flaked corn provided the inclusion rate does not exceed $20 \%$ of diet dry matter.

\section{Keywords}

Corn Grain, Extruded, Steam Flaked, Feedlot, Cattle

\section{Introduction}

The objective of grain processing is to improve feeding value and acceptability without detrimentally affecting digestive function [1]. Steam flaking corn can maximize its feeding value, largely due to enhancement of both ruminal and post-ruminal starch digestion [2] [3] [4]. Grain extrusion is a process by which ground grain is preconditioned with steam before being forced through perforated die and cut to size. Like steam flaking, extruding corn disrupts the starch matrix. Matsushima [5] proposed that extruded grains are comparable to steam-flaked grains. However, the effects of extrusion are generally more intense, resulting in a greater degree of chemical and structural transformations, including protein denaturation and starch gelatinization [6] [7], greatly enhancing starch enzymatic reactivity [8] [9]. In a direct comparison of dry rolled vs extruded corn (79\% of diet DM), Gaebe et al. [10] observed that extruded corn markedly depressed DMI and ADG of feedlot steers. Depressed intake was attributed to protracted low ruminal $\mathrm{pH}$ of steers fed extruded corn. In a companion digestion trial, they observed that whereas extrusion markedly increased (13\%) starch digestion, diet DE was not improved. This was attributed to low ruminal $\mathrm{pH}$ and negative associative effects on digestion of other dietary ingredients. Nevertheless, ruminal in situ comparisons demonstrated that rate of starch disappearance over time was more gradual for extruded corn vs ground corn [10]. The provision of fermentable substrate over a more prolonged period of time could have positive implications on ruminal microbial efficiency. The objective of the present study was to evaluate potential positive associative effects of extruded corn, when fed as only a partial replacement for steam flaked corn, on growth performance and characteristics of digestion in feedlot cattle.

\section{Materials and Methods}

All procedures involving animal care and management were in accordance with and approved by the University of California, Davis, Animal Use and Care Committee.

\subsection{Experiment 1, Growth Performance and Dietary Energetics}

Sixty-four Holstein steers with an average weight of $247 \pm 4 \mathrm{~kg}$ were used in a 70-d experiment to evaluate the effects of partial replacement of steam flaked 
corn (SFC) with extruded corn meal (EC; Matrix Nutrition, Chandler, AZ) in a finishing diet on growth performance and dietary net energy. Steers were blocked by initial weight into four weight groupings, and randomly assigned within weight groupings to 16 pens (4 steers per pen).Pens were $43 \mathrm{~m}^{2}$ with 22 $\mathrm{m}^{2}$ of overhead shade, automatic waters, and $2.4 \mathrm{~m}$ fence-line feed bunks. Treatments consisted of a steam flaked corn-based finishing diet containing $0 \%$, $10 \%, 20 \%$, or $30 \%$ EC, where EC replaced $0 \%, 15 \%, 30 \%$, or $45 \%$ of SFC (DM basis). The SFC was prepared as follows. A chest situated directly above the rollers ( $46 \times 61 \mathrm{~cm}$ corrugated) was filled with corn and then brought to a constant temperature at atmospheric pressure of $102^{\circ} \mathrm{C}$ using steam. Corn was steamed for approximately $20 \mathrm{~min}$ before starting the rollers. The first approximately 441 $\mathrm{kg}$ of steam-flaked grain was allowed to pass from the rollers before material was collected for use in the trial. This preliminary period served for warming the rolls and for adjusting the tension on the rolls to provide a flake density of 0.31 $\mathrm{kg} / \mathrm{L}$ (24 lbs/bushel). The SFC was then allowed to air-dry for 3 days before feeding. Ingredient and nutrient composition of experimental diets are shown in Table 1. Diets were prepared at weekly intervals and stored in plywood boxes located in front of each pen. Steers were allowed ad libitum access to their experimental diets. Fresh feed twice daily at 06:00 and 14:00 h, allowing for approximately 5\% residual. All steers were provided ad libitum access to water. Individual steers were weighed upon initiation and completion of the trial. In the calculation of steer performance live weights were reduce $4 \%$ to adjust for digestive tract fill. Estimates of steer performance were based on pen means.

Energy gain (EG) was calculated by the equation: $\mathrm{EG}=\mathrm{ADG}^{1.097} \cdot 0.0557 \mathrm{~W}^{0.75}$, where EG is the daily energy deposited ( $\mathrm{Mcal} / \mathrm{d}), \mathrm{W}$ is the mean shrunk body weight (kg; [11]). Maintenance energy (EM) was calculated by the equation: EM $=0.084 \mathrm{~W}^{0.75}$ [12]. Dry matter intake (DMI) is related to EM and dietary NEm according to the equation: $\mathrm{DMI}=\mathrm{EM} / \mathrm{NEm}+\mathrm{EG} /(0.877 \mathrm{NEm}-0.41)$, and can be resolved for estimation of dietary NEm by means of the quadratic formula: $\mathrm{x}$ $=\left[-\mathrm{b} \pm\left(\mathrm{b}^{2}-4 \mathrm{ac}\right)^{0.5}\right] / 2 \mathrm{a}$, where $\mathrm{x}=\mathrm{NEm}, \mathrm{a}=-0.877 \mathrm{DMI}, \mathrm{b}=0.877 \mathrm{EM}+0.41$ $\mathrm{DMI}+\mathrm{EG}$, and $\mathrm{c}=-0.42 \mathrm{EM}[13]$. Dietary net energy for gain $(\mathrm{NEg})$ was derived from NEm by the equation: $\mathrm{NEg}=0.877 \mathrm{NEm}-0.41$ [13].

Pens were used as experimental units. The experimental data were analyzed as a randomized complete block design experiment according to the following statistical model:

$$
Y_{i j}=\mu+B_{i}+T_{j}+E_{i j}
$$

where $\mu$ is the common experimental effect, $B_{i}$ represents initial weight group effect $(\mathrm{df}=3), T_{j}$ represents dietary treatment effect $(\mathrm{df}=3)$, and $E_{i j}$ represents the residual error $(d f=9)$. Treatments effects were tested using the linear, quadratic and cubic polynomials (Statistix 10, Analytical Software, Tallahassee, FL).

\subsection{Experiment 2, Digestive Function of Steers}

Four Holstein steers $(210 \pm 7 \mathrm{~kg})$ with cannulas in the rumen $(3.8 \mathrm{~cm}$ internal 
Table 1. Ingredients and composition of experimental diets fed to steers.

\begin{tabular}{|c|c|c|c|c|}
\hline & \multicolumn{4}{|c|}{ Extruded corn meal, $\%$ of $\mathrm{DMB}^{1}$} \\
\hline Item & 0 & 10 & 20 & 30 \\
\hline \multicolumn{5}{|c|}{ Ingredient } \\
\hline Sorghum Sudan, hay & 12.00 & 12.00 & 12.00 & 12.00 \\
\hline Yellow grease & 3.00 & 3.00 & 3.00 & 3.00 \\
\hline Molasses, cane & 4.00 & 4.00 & 4.00 & 4.00 \\
\hline Distillers grains, dried, with solubles & 10.00 & 10.00 & 10.00 & 10.00 \\
\hline Steam flaked corn ${ }^{2}$ & 67.53 & 57.53 & 47.53 & 37.53 \\
\hline Extruded corn meal ${ }^{3}$ & 0 & 10.00 & 20.00 & 30.00 \\
\hline Urea & 1.30 & 1.30 & 1.30 & 1.30 \\
\hline Limestone & 1.70 & 1.70 & 1.70 & 1.70 \\
\hline Rumensin 90, mg/lb & 0.0184 & 0.0184 & 0.0184 & 0.0184 \\
\hline Magnesium oxide & 0.15 & 0.15 & 0.15 & 0.15 \\
\hline TM salt ${ }^{4}$ & 0.30 & 0.30 & 0.30 & 0.30 \\
\hline \multicolumn{5}{|c|}{ Nutrient composition, DM basis ${ }^{5}$} \\
\hline Dry matter, $\%$ & 88.8 & 89.0 & 89.2 & 89.4 \\
\hline $\mathrm{NEm}, \mathrm{Mcal} / \mathrm{kg}$ & 2.21 & 2.21 & 2.21 & 2.21 \\
\hline NEg, Mcal/kg & 1.54 & 1.54 & 1.54 & 1.54 \\
\hline Crude protein, $\%$ & 14.2 & 14.2 & 14.2 & 14.2 \\
\hline Rumen DIP, \% & 61.8 & 61.8 & 61.8 & 61.8 \\
\hline Rumen UIP, \% & 38.2 & 38.2 & 38.2 & 38.2 \\
\hline Ether extract, \% & 7.10 & 7.10 & 7.10 & 7.10 \\
\hline Ash, \% & 5.70 & 5.70 & 5.70 & 5.70 \\
\hline NDF, \% & 18.6 & 18.6 & 18.6 & 18.6 \\
\hline Calcium, \% & 0.75 & 0.75 & 0.75 & 0.75 \\
\hline Phosphorus, \% & 0.34 & 0.34 & 0.34 & 0.34 \\
\hline Potassium, \% & 0.75 & 0.75 & 0.75 & 0.75 \\
\hline Magnesium, \% & 0.29 & 0.29 & 0.29 & 0.29 \\
\hline Sulfur, \% & 0.16 & 0.16 & 0.16 & 0.16 \\
\hline
\end{tabular}

${ }^{1} \mathrm{DMB}=$ Dry matter basis; ${ }^{2}$ Analyzed chemical composition for crude protein, NDF, starch and soluble (amyloglucosidase reactivity) starch were $8.4 \%, 10.9 \%$ and $72.4 \%$, and $8.6 \%$ (DM basis), respectively; ${ }^{3}$ Analyzed chemical composition for crude protein, NDF, starch and soluble (amyloglucosidase reactivity) starch were $8.7 \%, 10.3 \%, 69.8 \%$ and $30.9 \%$ (DM basis), respectively; ${ }^{4}$ Trace mineral salt contained: $\mathrm{CoSO}_{4}$, 0.068\%; $\mathrm{CuSO}_{4}, 1.04 \% ; \mathrm{FeSO}_{4}, 3.57 \% ; \mathrm{ZnO}, 1.24 \% ; \mathrm{MnSO}_{4}, 1.07 \%$; KI, $0.052 \%$; and $\mathrm{NaCl}, 92.96 \%$; ${ }^{5}$ Based on tabular values for individual feed ingredients [12].

diameter) and proximal duodenum [14] were used in a $4 \times 4$ Latin square experiment to evaluate treatment effects on characteristics of ruminal and total tract digestion. Dietary treatments were the same as indicated for Trial 1 (Table 1) with the inclusion of chromic oxide $(2.5 \mathrm{~g} / \mathrm{kg})$ as a digesta marker. Steers were maintained in individual pens $\left(5.6 \mathrm{~m}^{2}\right)$ with automatic waters. Diets were fed at 
0800 and $2000 \mathrm{~h}$ daily. In order to avoid the complications of feed refusals, DMI was restricted to $4.5 \mathrm{~kg} / \mathrm{d}$. Experimental periods were $14 \mathrm{~d}$, with $10 \mathrm{~d}$ for dietary treatment adjustment and $4 \mathrm{~d}$ for collection. Between each experimental period there was a 7 -d time-frame to recovery during which all steers were fed the control diet ( $0 \%$ extruded corn meal diet). During collection, duodenal and fecal samples were taken twice daily as follows: day 1, 0750 and $1350 \mathrm{~h}$; day 2, 0900 and $1500 \mathrm{~h}$; day 3,1050 and $1650 \mathrm{~h}$, and day 4, 1200 and $1800 \mathrm{~h}$. Individual samples consisted of approximately $700 \mathrm{~mL}$ of duodenal chyme and $200 \mathrm{~g}$ (wet basis) of fecal material. Samples from each steer within each collection period were composited for analysis. During the final day of each collection period, ruminal samples were obtained from each steer via ruminal cannula $4 \mathrm{~h}$ after feeding. Ruminal fluid $\mathrm{pH}$ was determined on fresh samples. Samples were strained through 4 layers of cheesecloth. Two milliliters of freshly prepared $(25 \mathrm{~g} / 100$ $\mathrm{mL}$ ) meta-phosphoric acid was added to $8 \mathrm{~mL}$ of strained ruminal fluid. Samples were then centrifuged $(17,000 \times \mathrm{g}$ for $10 \mathrm{~min})$, and supernatant fluid was stored at $-20^{\circ} \mathrm{C}$ for VFA analysis. Upon completion of the experiment, ruminal fluid was obtained via the ruminal cannula from all steers and composited for isolation of ruminal bacteria by differential centrifugation [15].

Corn, feed and fecal samples were subjected all or part of the following analysis: DM (oven drying at $105^{\circ} \mathrm{C}$ until no further weight loss); ash (method 942.05, AOAC [16]), Kjeldahl N (method 984.13, AOAC [17]); aNDFom (Van Soest et al. [18] corrected for NDF-ash, incorporating heat stable $\alpha$-amylase (Ankom FAA, Ankom Technology, Macedon, NY) at $1 \mathrm{~mL}$ per $100 \mathrm{~mL}$ of NDF solution); chromic oxide [19]; starch content and changes in starch solubility as a result of corn processing were determined using amyloglucosidase [20]. Duodenal samples were subjected the following analysis: DM (oven drying at $105^{\circ} \mathrm{C}$ until no further weight loss); ash (method 942.05, AOAC [16]), Kjeldahl N (method 984.13, AOAC [17]), ammonia N (method 941.04, AOAC [17]); aNDFom (Van Soest et al. [18], corrected for NDF-ash, incorporating heat stable $\alpha$-amylase (Ankom FAA, Ankom Technology, Macedon, NY) at $1 \mathrm{~mL}$ per $100 \mathrm{~mL}$ of NDF solution); purines [21]; chromic oxide [19]; and starch [20]. Concentrations of VFA in ruminal fluid were determined by gas chromatography using a DB-FFAP Megabore column (30 m $\times 0.530 \mathrm{~mm}$, J \& W Scientific, Folsom, CA). Column, inlet and detector temperatures were maintained at $130^{\circ}, 195^{\circ}$, and $200^{\circ} \mathrm{C}$, respectively, with carrier gas $(\mathrm{N})$ flow rate at $20 \mathrm{~mL} / \mathrm{min}$.

Total DM flow to the duodenum and fecal excretion were estimated based on marker ratio: the relationship of $\mathrm{Cr}$ intake $(\mathrm{g})$ vs. concentration of $\mathrm{Cr}$ in duodenal and fecal samples. Microbial organic matter (MOM) and $\mathrm{N}(\mathrm{MN})$ leaving the abomasum was calculated using purines as a microbial marker [21]. Organic matter fermented in the rumen was considered equal to OM intake minus the difference between the amount of total OM reaching the duodenum and MOM reaching the duodenum. Feed $\mathrm{N}$ escape to the small intestine was considered equal to total $\mathrm{N}$ entering the duodenum minus ammonia- $\mathrm{N}, \mathrm{MN}$ and endogenous $\mathrm{N}\left(0.195 \times \mathrm{BW}^{0.75}\right.$, Ørskov et al. [22]). Methane production ( $\mathrm{mol} / \mathrm{mol}$ glu- 
cose equivalent fermented) was estimated based on the theoretical fermentation balance for observed molar distribution of VFA [23].

The effects of extruded corn meal level in diet $(0,10,20$, or $30 \%)$ on characteristics of digestion in cattle were analyzed as a balanced $4 \times 4$ Latin square design experiment:

$$
Y_{i j k}=\mu+S_{i}+P_{j}+T_{k}+E_{i j k l}
$$

where: $Y_{i j k}$ is the response variable, $\mu$ is the common experimental effect, $S_{i}$ is the steer effect, $P_{j}$ is the period effect, $T_{k}$ is the treatment effect and $E_{i j k}$ is the residual error. Treatments effects were tested by means of linear and quadratic polynomials (Statistix 10, Analytical Software, Tallahassee, FL).

\section{Results and Discussion}

As expected, $\mathrm{CP}, \mathrm{NDF}$ and starch content of EC were similar to that of SFC (104\%, 94\% and 96\%, respectively). In contrast, soluble starch (a measure of disruption of the starch matrix) was markedly (359\%) greater for EC (Table 1). Both steam flaking and extrusion disrupt the starch granule matrix. However, with extrusion the thermal energy transfer and shear stress are more intense, causinga greater degree of chemical and structural transformations, including protein denaturation and starch gelatinization [6] [7] [8] [9]. With respect to steam flaking, degree of processing (flake density, steaming time, tempering) effects changes in starch enzymatic reactivity and characteristics of digestion [3] [24] [25]. However, the relationship between degree of starch gelatinization/solubility brought on by the extrusion process on characteristics of ruminal and total tract digestion has not been assessed [26]

Treatment effects on growth-performance of feedlot steers and estimated net energy values of dietary treatments are shown in Table 2 . The primary goal of grain processing is to enhance feeding value and diet acceptability in a manner that will improve growth-performance with minimal detrimental effects on digestive function [1]. Partial replacement of SFC with increasing levels of EC did not affect $(P>0.10)$ ADG, DMI, gain efficiency, and dietary net energy. When SFC replaces dry processed corn in finishing diets, feedlot cattle ADG, gain efficiency and dietary NE are appreciably enhanced [1]. In contrast, substitution of dry rolled corn with EC (79\% of diet DM) markedly depressed feedlot cattle ADG and gain efficiency [10]. Depressed intake was attributed to protracted low ruminal $\mathrm{pH}$ of steers fed EC. Nevertheless, when EC was fed as only a partial replacement for SFC we did not observe marked negative effects on growth-performance.

Observed dietary NE values for the basal SFC-based diet were in good (97\%) agreement with expected based on tabular feed values [12]. When EC replaced $15 \%$ to $30 \%$ of SFC observed dietary NE was $99 \%$ of expected. Whereas, when EC replaced $45 \%$ of SFC observed dietary NE was $94 \%$ of expected. These numerical differences in observed dietary NE were not statistically appreciable ( $P=$ $0.18)$.

Treatment effects on characteristics of digestion are shown in Table 3. Partial 
Table 2. Influence of partial replacement of steam flaked corn with extruded corn on growth-performance of feedlot steers and net energy value of the diet.

\begin{tabular}{|c|c|c|c|c|c|c|c|}
\hline \multicolumn{7}{|c|}{ Extruded corn meal, \% of DM } & \multirow{2}{*}{$\begin{array}{c}P \text { value } \\
\text { Quadratic }\end{array}$} \\
\hline Item & 0 & 10 & 20 & 30 & SEM & Linear & \\
\hline \multicolumn{8}{|l|}{$\mathrm{BW}^{1}, \mathrm{~kg}$} \\
\hline Initial & 246 & 247 & 244 & 251 & 1.8 & 0.23 & 0.12 \\
\hline Final & 340 & 346 & 338 & 343 & 3.9 & 0.90 & 0.93 \\
\hline $\mathrm{ADG}, \mathrm{kg} / \mathrm{d}$ & 1.34 & 1.42 & 1.35 & 1.32 & 0.04 & 0.55 & 0.29 \\
\hline DMI, kg/d & 6.50 & 6.69 & 6.37 & 6.74 & 0.14 & 0.58 & 0.56 \\
\hline Gain: Feed & 0.210 & 0.210 & 0.210 & 0.190 & 0.006 & 0.30 & 0.13 \\
\hline \multicolumn{8}{|c|}{ Dietary NE, Mcal/kg } \\
\hline Maintenance & 2.15 & 2.18 & 2.19 & 2.09 & 0.04 & 0.38 & 0.18 \\
\hline Gain & 1.48 & 1.51 & 1.51 & 1.42 & 0.04 & 0.38 & 0.18 \\
\hline \multicolumn{8}{|c|}{ Observed/expected dietary NE } \\
\hline Maintenance & 0.97 & 0.99 & 0.99 & 0.94 & 0.02 & 0.38 & 0.18 \\
\hline Gain & 0.97 & 0.99 & 0.99 & 0.93 & 0.03 & 0.38 & 0.18 \\
\hline
\end{tabular}

${ }^{1}$ Initial and final BW reduced $4 \%$ to account for digestive tract fill.

Table 3. Influence of partial replacement of steam flaked corn with extruded corn on characteristics of ruminal and total tract digestion.

\begin{tabular}{|c|c|c|c|c|c|c|c|}
\hline \multirow[b]{2}{*}{ Item } & \multicolumn{4}{|c|}{ Extruded corn meal, \% of DM } & \multicolumn{3}{|c|}{$P$ value } \\
\hline & 0 & 10 & 20 & 30 & SEM & Linear & Quadratic \\
\hline \multicolumn{8}{|l|}{ Intake, $\mathrm{g} / \mathrm{d}$} \\
\hline $\mathrm{DM}^{1}$ & 4453 & 4475 & 4498 & 4520 & & & \\
\hline $\mathrm{OM}$ & 4224 & 4246 & 4269 & 4292 & & & \\
\hline $\mathrm{NDF}$ & 693 & 706 & 718 & 731 & & & \\
\hline $\mathrm{N}$ & 97 & 97 & 97 & 97 & & & \\
\hline Starch & 2275 & 2282 & 2288 & 2294 & & & \\
\hline $\mathrm{GE}, \mathrm{Mcal} / \mathrm{d}$ & 19.02 & 19.12 & 19.22 & 19.31 & & & \\
\hline \multicolumn{8}{|c|}{ Leaving abomasum, g/d } \\
\hline $\mathrm{OM}$ & 1909 & 1935 & 2048 & 1970 & 85.5 & 0.45 & 0.55 \\
\hline $\mathrm{NDF}$ & 332 & 343 & 351 & 379 & 21.7 & 0.15 & 0.70 \\
\hline Starch & 256 & 259 & 284 & 303 & 22.5 & 0.12 & 0.74 \\
\hline Ammonia $\mathrm{N}$ & 4.49 & 4.31 & 3.62 & 3.81 & 0.1 & $<0.01$ & 0.21 \\
\hline Non-ammonia $\mathrm{N}$ & 96.5 & 96.7 & 104 & 96.8 & 3.2 & 0.60 & 0.30 \\
\hline Microbial N & 57.2 & 55.3 & 58.0 & 57.0 & 2.3 & 0.86 & 0.86 \\
\hline Feed N & 28.5 & 30.6 & 34.7 & 29.1 & 3.5 & 0.72 & 0.29 \\
\hline \multicolumn{8}{|l|}{ Ruminal digestion, \% } \\
\hline $\mathrm{OM}$ & 68.4 & 67.5 & 65.6 & 67.4 & 1.8 & 0.57 & 0.49 \\
\hline
\end{tabular}




\section{Continued}

\begin{tabular}{|c|c|c|c|c|c|c|c|}
\hline NDF & 52.1 & 51.5 & 51.1 & 48.2 & 3.1 & 0.40 & 0.72 \\
\hline Starch & 88.8 & 88.6 & 87.6 & 86.8 & 0.009 & 0.14 & 0.74 \\
\hline Feed N & 70.6 & 68.4 & 64.3 & 70.2 & 3.6 & 0.74 & 0.29 \\
\hline Microbial N efficiency ${ }^{2}$ & 20.0 & 19.5 & 20.8 & 19.8 & 1.1 & 0.87 & 0.81 \\
\hline Protein Efficiency ${ }^{3}$ & 1.00 & 1.00 & 1.06 & 0.99 & 0.03 & 0.68 & 0.30 \\
\hline \multicolumn{8}{|l|}{ Fecal excretion, g/d } \\
\hline $\mathrm{DM}$ & 840 & 942 & 933 & 1034 & 42 & 0.01 & 0.99 \\
\hline $\mathrm{OM}$ & 721 & 810 & 802 & 989 & 40 & 0.01 & 0.92 \\
\hline $\mathrm{NDF}$ & 358 & 406 & 383 & 439 & 21 & 0.04 & 0.85 \\
\hline Starch & 9.26 & 10.3 & 11.0 & 16.3 & 1.81 & 0.02 & 0.26 \\
\hline $\mathrm{N}$ & 26.7 & 28.4 & 29.6 & 31.5 & 1.6 & 0.05 & 0.96 \\
\hline GE, Mcal/d & 3.71 & 4.09 & 4.10 & 4.57 & 0.21 & 0.02 & 0.84 \\
\hline \multicolumn{8}{|l|}{ Total tract digestion, $\%$} \\
\hline $\mathrm{DM}$ & 81.1 & 79.0 & 79.3 & 77.1 & 0.93 & 0.02 & 0.98 \\
\hline $\mathrm{OM}$ & 82.9 & 80.9 & 81.2 & 79.1 & 0.93 & 0.02 & 0.93 \\
\hline $\mathrm{NDF}$ & 48.4 & 42.5 & 46.7 & 39.9 & 2.9 & 0.13 & 0.88 \\
\hline $\mathrm{N}$ & 72.4 & 70.8 & 69.5 & 67.7 & 1.6 & 0.06 & 0.97 \\
\hline Starch & 99.6 & 99.6 & 99.5 & 99.3 & 0.09 & 0.03 & 0.30 \\
\hline $\mathrm{DE} \operatorname{diet}(\mathrm{Mcal} / \mathrm{kg})$ & 3.44 & 3.36 & 3.36 & 3.26 & 0.05 & 0.03 & 0.85 \\
\hline DE (\%) & 80.5 & 78.6 & 78.6 & 76.4 & 1.1 & 0.03 & 0.85 \\
\hline
\end{tabular}

${ }^{1} \mathrm{DMI}$ was restricted to $2.15 \%$ of BW daily; ${ }^{2}$ Microbial N, g/kg OM fermented; ${ }^{3}$ Nonammonia $\mathrm{N}$ flow to the small intestine as a fraction of $\mathrm{N}$ intake.

replacement of SFC with EC resulted in a numerically small, but appreciable decrease (linear effect, $P<0.01$ ) in flow of ammonia $\mathrm{N}$ to the small intestine. However, there were no treatment effects $(P>0.10)$ on flow of non-ammonia $\mathrm{N}$, undegraded feed $\mathrm{N}$ and microbial $\mathrm{N}$ to the small intestine, and ruminal microbial $\mathrm{N}$ efficiency (g microbial N/kg OM fermented). Likewise, there were no treatment effects $(P>0.10)$ on ruminal digestion of OM, NDF, starch and feed $\mathrm{N}$.

As expected, total tract digestion of starch for all treatments exceeded $99 \%$. Notwithstanding, replacing SFC with EC decreased total tract digestion of DM and OM (linear effect, $P=0.02$ ), and dietary DE (linear effect, $P=0.03$ ). Consistent with Trial 1, the effect was more pronounced where EC replaced $45 \%$ of SFC.

Substituting SFC with EC did not affect $(P>0.10)$ ruminal $\mathrm{pH}$, total VFA concentration, molar proportions of acetate, propionate, butyrate and isovalerate, and estimated methane production (Table 4). Ruminal pH (4 hours postprandial) averaged $5.68 \pm 0.03$. Generally, ruminal proteolytic activity does not decrease as $\mathrm{pH}$ decrease in cattle fed high-concentrate diets [27]. However, microbial efficiency is affected as greater energy is expended to maintain intracellular pH [28]. Partial replacement of SFC with EC increased (linear effect, $P<$ 
Table 4. Influence of partial replacement of steam flaked corn with extruded corn on ruminal $\mathrm{pH}, \mathrm{VFA}$ molar proportions, and estimated methane production ${ }^{1}$.

\begin{tabular}{|c|c|c|c|c|c|c|c|}
\hline \multicolumn{6}{|c|}{ Extruded corn meal, \% of DM } & \multicolumn{2}{|c|}{$P$ value } \\
\hline Item & 0 & 10 & 20 & 30 & SEM & Linear & Quadratic \\
\hline Rumen pH & 5.69 & 5.72 & 5.65 & 5.65 & 0.16 & 0.78 & 0.92 \\
\hline Total VFA, mM & 107 & 107 & 107 & 116 & 6.57 & 0.36 & 0.46 \\
\hline \multicolumn{8}{|c|}{ Rumen VFA, mol/100 mol } \\
\hline Acetate & 52.5 & 54.8 & 54.9 & 49.2 & 3.54 & 0.55 & 0.28 \\
\hline Propionate & 33.5 & 30.4 & 28.6 & 33.6 & 3.44 & 0.92 & 0.26 \\
\hline Isobutyrate & 0.43 & 0.53 & 0.54 & 0.56 & 0.10 & 0.43 & 0.70 \\
\hline Butyrate & 10.7 & 11.0 & 12.5 & 12.2 & 1.33 & 0.33 & 0.83 \\
\hline Isovalerate & 1.77 & 2.28 & 1.86 & 2.81 & 0.46 & 0.22 & 0.64 \\
\hline Valerate & 1.14 & 1.03 & 1.61 & 1.66 & 0.14 & $<0.01$ & 0.57 \\
\hline Acetate: propionate & 1.68 & 2.25 & 2.00 & 1.48 & 0.44 & 0.67 & 0.24 \\
\hline Methane $^{2}$ & 0.43 & 0.47 & 0.49 & 0.42 & 0.05 & 0.90 & 0.26 \\
\hline
\end{tabular}

${ }^{1} \mathrm{DMI}$ was restricted to $2.15 \%$ of $\mathrm{BW} ;{ }^{2} \mathrm{Methane}, \mathrm{mol} / \mathrm{mol}$ glucose equivalent fermented.

0.01) ruminal molar proportions of valerate. The basis for this is not certain. However, it may reflect the increased denaturation and solubilization of corn protein during the extrusion process, as changes in valerate concentrations reflect ruminal protein degradation. When proline undergoes reductive ring cleavage and deamination it yields valerate [29].

\section{Conclusion}

Partial replacement of steam flaked corn with extruded corn does not have a beneficial effect on ruminal microbial efficiency and digestive function. The feeding value of extruded corn for feedlot cattle is comparable to that of steam flaked corn provided the inclusion rate does not exceed $20 \%$ of diet dry matter.

\section{Conflicts of Interest}

The authors declare no conflicts of interest regarding the publication of this paper.

\section{References}

[1] Zinn, R.A., Barreras, A., Corona, L., Owens, F.N. and Plascencia, A. (2011) Comparative Effects of Processing Methods on the Feeding Value of Maize in Feedlot Cattle. Nutrition Research Reviews, 24, 183-190.

https://doi.org/10.1017/S0954422411000096

[2] Zinn, R.A. (1990) Influence of Steaming Time on Site of Digestion of Flaked Corn in Steers. Journal of Animal Science, 68, 776-781. https://doi.org/10.2527/1990.683776x

[3] Corona, L., Rodriguez, S., Ware, R.A. and Zinn, R.A. (2005) Comparative Effects of Whole, Ground, Dry-Rolled, and Steam-Flaked Corn on Digestion and Growth 
Performance in Feedlot Cattle. The Professional Animal Scientist, 21, 200-206. https://doi.org/10.15232/S1080-7446(15)31203-1

[4] Plascencia, A., Bermúdez, R.M., Cervantes, M., Corona, L., Dávila-Ramos, H., López-Soto, M.A., May, D., Torrentera, N.G. and Zinn, R.A. (2011) Influence of Processing Method on Comparative Digestion of White Corn versus Conventional Steam-Flaked Yellow Dent Corn in Finishing Diets for Feedlot Cattle. Journal of Animal Science, 89, 136-141. https://doi.org/10.2527/jas.2010-3116

[5] Matsushima, J.K. (1979) Chapter 4, Processing Feeds for Beef Cattle. In: Feeding Beef Cattle, Springer, Berlin, Heidelberg, 81-92.

[6] Lai, L.S. and Kokini, J.L. (1991) Physicochemical Changes and Rheological Properties of Starch during Extrusion. Biotechnology Progress, 7, 251-266.

https://doi.org/10.1021/bp00009a009

[7] Ilo, S. and Berghofer, E. (1999) Kinetics of Colour Changes during Extrusion Cooking of Maize Grits. Journal of Food Engineering, 39, 73-80. https://doi.org/10.1016/S0260-8774(98)00148-4

[8] Dehghan-banadaky, M., Corbett, R. and Oba, M. (2007) Effects of Barley Grain Processing on Productivity of Cattle. Animal Feed Science and Technology, 137, $1-24$.

[9] Solanas, E., Castrillo, C., Serrano, X., Janacua, H., Fondevila, M. and Guada, J.A. (2005) Effect of Concentrate Extrusion and Castration on Diet Digestion and Performance of Intensively Reared Male Calves. Livestock Production Science, 94, 225-236.

[10] Gaebe, R.J., Sanson, D.W., Rush, I.G., Riley, M.L., Hixon, D.L. and Paisley, S.I. (1998) Effects of Extruded Corn or Grain Sorghum on Intake, Digestibility, Weight Gain, and Carcasses of Finishing Steers. Journal of Animal Science, 76, 2001-2007. https://doi.org/10.2527/1998.7682001x

[11] NRC (1984) Nutrient Requirements of Beef Cattle. 6th Edition, The National Academies Press, Washington DC.

[12] NRC (1996) Nutrient Requirements of Beef Cattle. 7th Edition, The National Academies Press, Washington DC.

[13] Zinn, R.A. and Shen, Y. (1998) An Evaluation of Ruminally Degradable Intake Protein and Metabolizable Amino Acid Requirements of Feedlot Calves. Journal of Animal Science, 76, 1280-1289. https://doi.org/10.2527/1998.7651280x

[14] Zinn, R.A. and Plascencia, A. (1993) Interaction of Whole Cottonseed and Supplemental Fat on Digestive Function in Cattle. Journal of Animal Science, 71, 11-17.

[15] Bergen, W.G., Purser, D.B. and Cline, J.H. (1968) Effect of Ration on the Nutritive Quality of Rumen Microbial Protein. Journal of Animal Science, 27, 1497-1501. https://doi.org/10.2527/jas1968.2751497x

[16] AOAC (1986) Official Methods of Analysis. 13th Edition, Washington DC.

[17] AOAC (2000) Official Methods of Analysis. 17th Edition, Gaithersburg, MD.

[18] Van Soest, P.J., Robertson, J.B. and Lewis, B.A. (1991) Methods for Dietary Fiber, Neutral Detergent Fiber, and Nonstarch Polysaccharides in Relation to Animal Nutrition. Journal of Dairy Science, 74, 3583-3597.

[19] Hill, F.N. and Anderson, D.L. (1958) Comparison of Metabolizable Energy and Productive Energy Determinations with Growing Chicks. The Journal of Nutrition. 64, 587-603. https://doi.org/10.1093/jn/64.4.587

[20] Zinn, R.A. (1990) Influence of Flake Density on the Comparative Feeding Value of Steam-Flaked Corn for Feedlot Cattle. Journal of Animal Science, 68, 767-775. 
[21] Zinn, R.A. and Owens, F.N. (1986) A Rapid Procedure for Purine Measurements and Its Use for Estimating Net Ruminal Protein Synthesis. Canadian Journal of Animal Science, 66, 157-166. https://doi.org/10.4141/cjas86-017

[22] Ørskov, E.R., MacLeod, N.A. and Kyle, D.J. (1986) Flow of Nitrogen from the Rumen and Abomasum in Cattle and Sheep Given Protein-Free Nutrients by Intragastric Infusion. British Journal of Nutrition, 56, 241-248.

[23] Wolin, M.J. (1960) A Theoretical Rumen Fermentation Balance. Journal of Dairy Science, 43, 1452-1459.

[24] Zinn, R.A. (1987) Influence of Lasalocid and Monensin Plus Tylosin on Comparative Feeding Value of Steam-Flaked versus Dry-Rolled Corn Diets for Feedlot Cattle. Journal of Animal Science, 65, 256-266. https://doi.org/10.2527/jas1987.651256x

[25] Gutierrez, B.H., Alvarez, E.G., Montano, M.F., Salinas-Chavira, J., Torrentera, N.G. and Zinn, R.A. (2018) Influence of Flake Density and Tempering on the Feeding Value of Steam-Flaked Corn for Feedlot Cattle. Journal of Applied Animal Research, 46, 155-158. https://doi.org/10.1080/09712119.2017.1278699

[26] Rowe, J.B., Choct, M. and Pethick, D.W. (1999) Processing Cereal Grains for Animal Feeding. Australian Journal of Agricultural Research, 50, 721-736. https://doi.org/10.1071/AR98163

[27] Bach, A., Calsamiglia, S. and Stern, M.D. (2005) Nitrogen Metabolism in the Rumen. Journal of Dairy Science, 88, E9-E21. https://doi.org/10.3168/jds.S0022-0302(05)73133-7

[28] Dewhurst, R.J., Davies, D.R. and Merry, R.J. (2000) Microbial Protein Supply from the Rumen. Animal Feed Science and Technology, 85, 1-21. https://doi.org/10.1016/S0377-8401(00)00139-5

[29] Dehority, B.A., Johnson, R.R., Bentley, O.G. and Moxon, A.L. (1958) Studies on the Metabolism of Valine, Proline, Leucine and Isoleucine by Rumen Microorganisms in Vitro. Archives of Biochemistry and Biophysics, 78, 15-27. https://doi.org/10.1016/0003-9861(58)90310-2 